\title{
DESIGNING COMPUTER-BASED EXERCISES USING WEBLOG, HOT POTATOES SOFTWARE AND SKYPE MESSENGERS IN CREATING IDEAS TO FACILITATE INDEPENDENCE LEARNING OF READING COMPREHENSION \\ Lusy Tunik Muharlisiani+Anang Kukuh+Siti Azizah yahdillalusy@gmail.com+anang@anang65.web.id+sitiaziahazizah81@yahoo.com UNIVERSITAS WIJAYA KUSUMA SURABAYA
}

\begin{abstract}
The design-based research methodology explicates how design not only allowed more effective student representation and sharing of the different levels of knowledge required for abstraction to occur, but also enabled better teacher assessment and, hence, remediation also provides detailed guidance on creating interactive content (from the application of learning strategies and media to courseware development). On the basis of the emerging findings of the study a set of principles for designing web-conferencing (or other online) environments to support creative design learning is proposed. This mainly addresses trainers and instructional designers who aim to create learning projects that really match learners' needs, was considered appropriate and suitable for the students to develop their reading comprehension. This interactive and interesting design would increase the students' motivation to learn reading comprehension in fun environment. It is expected that they could change their habit of the learning by accessing the exercises regularly as the media
\end{abstract}

Key words: Weblog, Hot Potatoes Sofware, Skype Messengers, and Reading Comprehension INTRODUCTION

The use of teaching media, both in manual or electronic can motivate the students in order to follow the learning process. There are many kinds of technology, but this study focuses on the use of computer and certain software. Students need to bring to the experience of doing activities in the context of actual language. The way in which people represent and exchange design information has been proposed to critically affect the success of collaborative design processes. Langer and Levy (2007) found a significantly improved performance in a temporal design task when a visual representation was used. To achieve a good students' reading comprehension, teachers must implement an effective learning process, namely how to choose the media teaching characteristics according to the needs of students who have different intellectual or talent will help students improve optimum learning outcomes for students. So the teacher can use social media "Weblog, Hot Potatoes Software and Skype Messenger" Martindale (2004) says 1. Weblog and Hot Potatoes Software, and Skype Messengers are a set computer assisted language learning tools that the teacher easily creates interactive web-based exercise, 2 . They gave the students motivation to learn English such as increasing the exposure of the target language and increasing language learning, 3. They include six applications enabling the teacher to create interactive multiple-choice, shortanswer, jumbled-sentence, crossword, matching/ordering and gap-fill exercises and makes them available on web page

However, the teacher's control was still needed and has realized that computers as the supporting tools of teaching-learning process . In addition, it is expected that by operating the design, it enables the students to be familiar with the computer operating system in the case of English learning. According Dudeney, Gavin \& Hockly, Nicky. 2007; In teaching learning process as variation because variation will give the students the change of have pleasure in learning language. In this study the researcher uses social media weblog, hot 
potatoes software, and skype messenger as the media of teaching learning process because they are a new thing a nice variation so that the students will be attracted, interested in learning reading comprehension, can share a story, celebrate a birthday, learn a language, hold a meeting, work with colleagues - just about anything they need to do together every day, with the latest version, provides independent learning, so the students could access the supplementary exercises individually outside classroom in order to improve their reading comprehension.

Based on reason above, the researcher wants to present the alternative in choosing technique and material in order to achieve the goal of teaching reading comprehension. With Weblog, Hot Potatoes Software and Skype Messengers can increase students' ability in reading comprehension, wants to introduce a powerful tools and can be used to create a good atmosphere in a class

\section{The Special Research}

The main special research found out how to design a set of computer-based exercises using Weblog, Hot Potatoes Software and Skype Messengers for developing logical with integrated and created because that multimedia can be assesed anytime, facilitated independent learning in reading comprehension and presented the set of computer-based media exercises. Harmer, Jeremy. 2008 saya, they needed supplementary exercises which enabled them to improve their reading comprehension and to create entertaining environment of the learning at the sametime. Hence, computer-based exercises were chosen because it was very interesting learning, so their motivation to learn would be increased and also leaded them to learn independently because it could be accessed at anytime outside classroom. Besides, the software was chosen, it provided five interesting programs to do the exercises. Two research problems were formulated, namely first, how computer-based exercises was designed, and second, what the computer-based exercises looked like.

Design-based research involves iterative cycles of problem analysis, theory-based solution development, evaluation in real-world settings, and the development of situated design principles (Reeves \& Hedberg, 2009). Figure 2.1 
Predictive Research

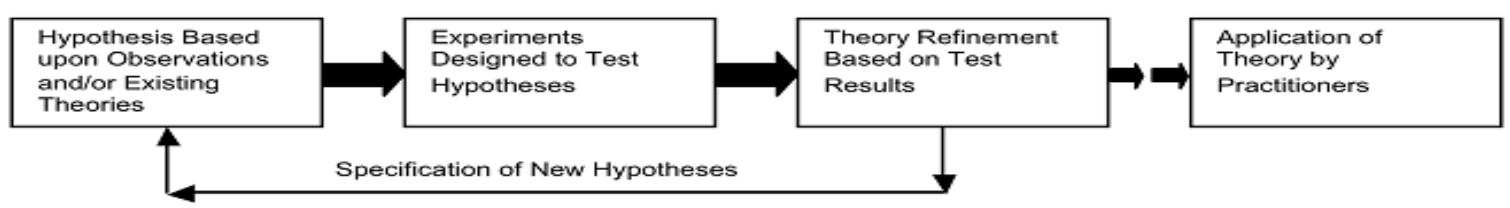

Design Research

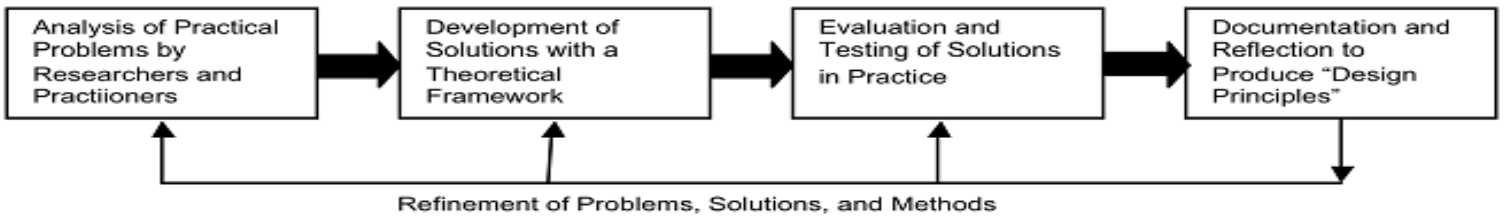

Figure 2.1 Difference between predictive and design research approaches (Reeves \& Hedberg, 2009) Design based research enables the use of any and all types of data to arrive at effective designs O’Malley, M.J. \& Pierce, V.L.(2005) which allowed the teacher's observations as well as students' interactions, contributions, discourse, and feedback to inform the redesign of the environment.

\subsection{The Flow Chart of the Design Process}

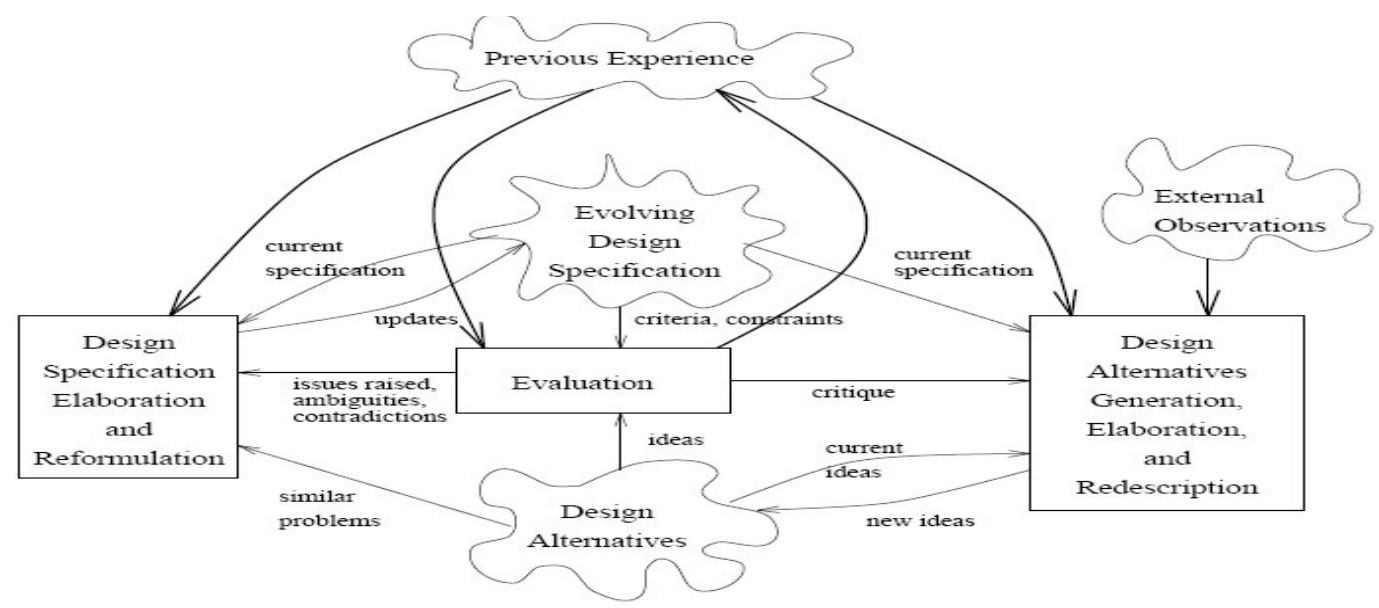

Figure 2.2. Creative design process

The full process Cohen, L Manion, L \& Marrison K. (2000) propose is shown in Figure 1. The process integrates reasoning needed tosolve problems and achieve challenges with the iterative evaluation, explanation, and redesign processes required for creativity This analysis tells us what needs to be learned to reason creatively: how and when to identify criteria and constraints (design specification in the figure); how to use criteria and constraints as evaluation criteria; how and when to generate alternative solutions, and especially how to use cases and one's own experiences to do that; how to use evaluation results to elaborate and 
reformulate alternative solutions (called design alternatives in the figure) and criteria and constraints; and how to identify when one has a good enough solution

To validate this design, the research conducted two kinds of preliminary form of product, namely trial of the product and content evaluation. The design was considered appropriate and suitable for the students to develop and focuse on comprehension.

\section{THE METHOD}

The application of research results in order to support the Construction and Development of Ipteks-sosbud. Hesmondhalgh (2011) Huette, Scott. 2006 says: There are three activities to be performed. (1) Trying of assesment widely about the design of its computer-based learning to the development of reasoning, (2) The improvement of the design of learning reading comprehension based computer by using weblog, hot potatoes software and skype messengers is to be worthy published, (3) Preparation of learning design based computer by using weblog, hot potatoes software and skype messengers to the development of a logical reasonable until ready to publish.

It is obtained by observing and recording the data required in the process of preproduction, production, and post production. Duffy, Peter and Bruns, Axel. 2006 says

Pre Production $\rightarrow$ There are several steps that are done in the making design of learning reading comprehension is ideas and concepts. Search for ideas and concepts conducted by lead director studio

\section{Production $\rightarrow$ The production process is carried out by tools}

a. Learning design reference Search by theme. It aims to get an overview of the design of learning reading comprehension to be made.

b. The process of rough sketches can be made after the design of learning reading comprehension has been obtained.

c. After the sketch and one of alternative design was approved. Then the steps to make vector can do.

\section{Pasca Production: According Gabriella Sandya Puspita Sari. 071214027 (2012)}

a. Finishing, This stage done prior to the design of learning reading comprehension goes into the process of programming the software hot potatoes.

b. Game programming $\rightarrow$ this stage is the process of a merger between the learning design with a program that runs the design

c. Testing $\rightarrow$ this step is learning to design trials students in learning reading comprehension by means of dissemination of student satisfaction questionnaire against the design software hot potatoes that have been made 


\section{The Observations}

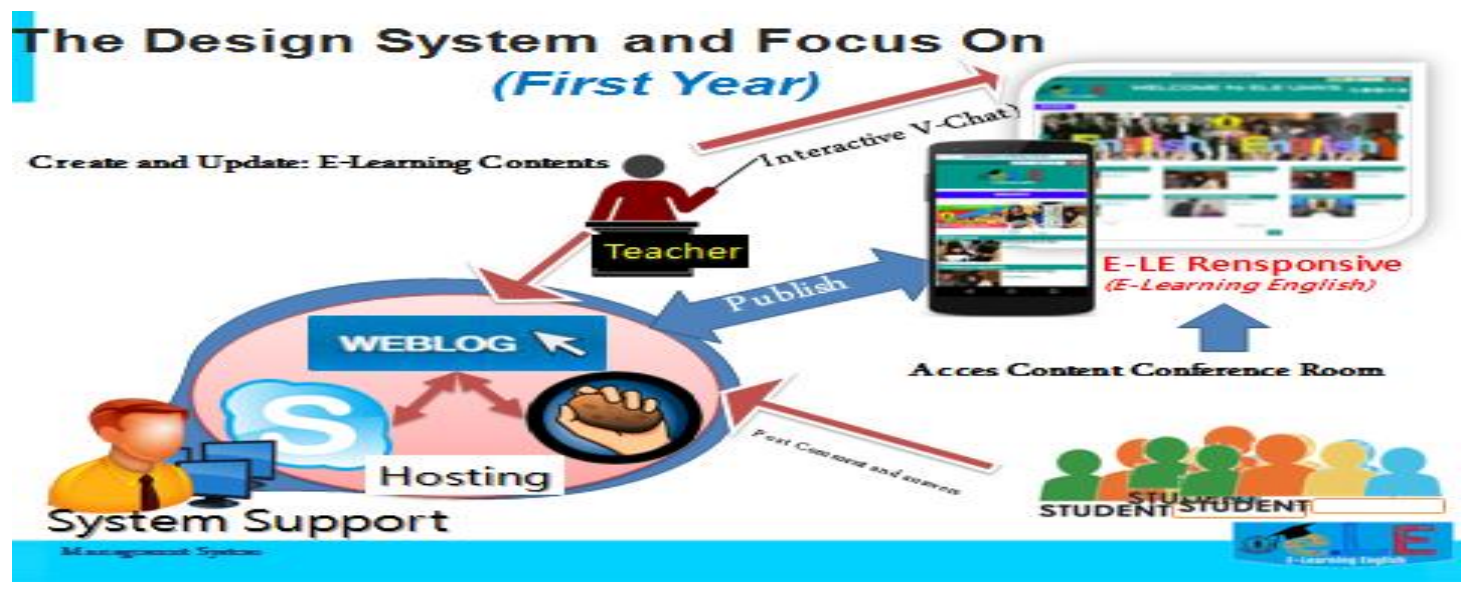

In the first year still the design and focus on

a. Interactive video covering (chat and conference)

b. Responsive web base and mobile application

In the second year is the roadmap implementation of design

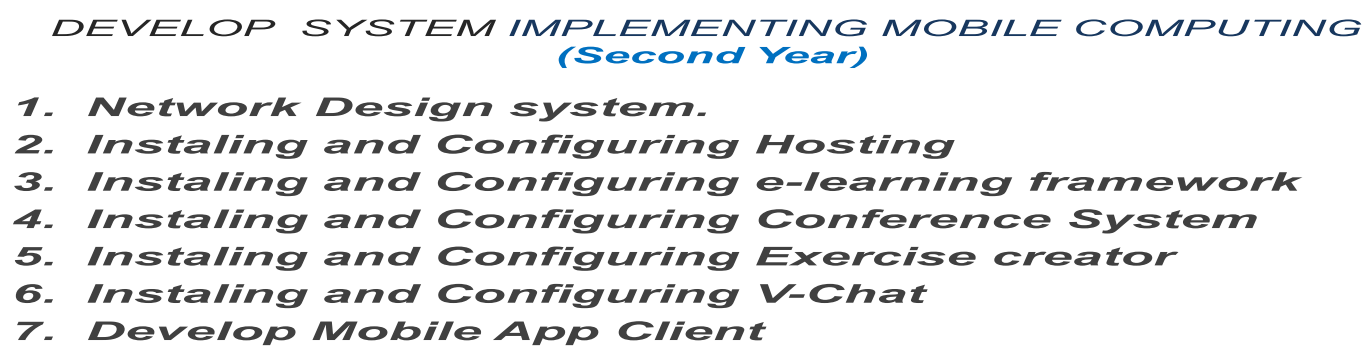

The stage for the implementation system:
a. Making server
b. Hosting as a web base and a database
c. Configuration framework e learning
d. Configuration system for conference
e. Configuration making questions
f. Configuration to video chat
g. Making application users mobile based

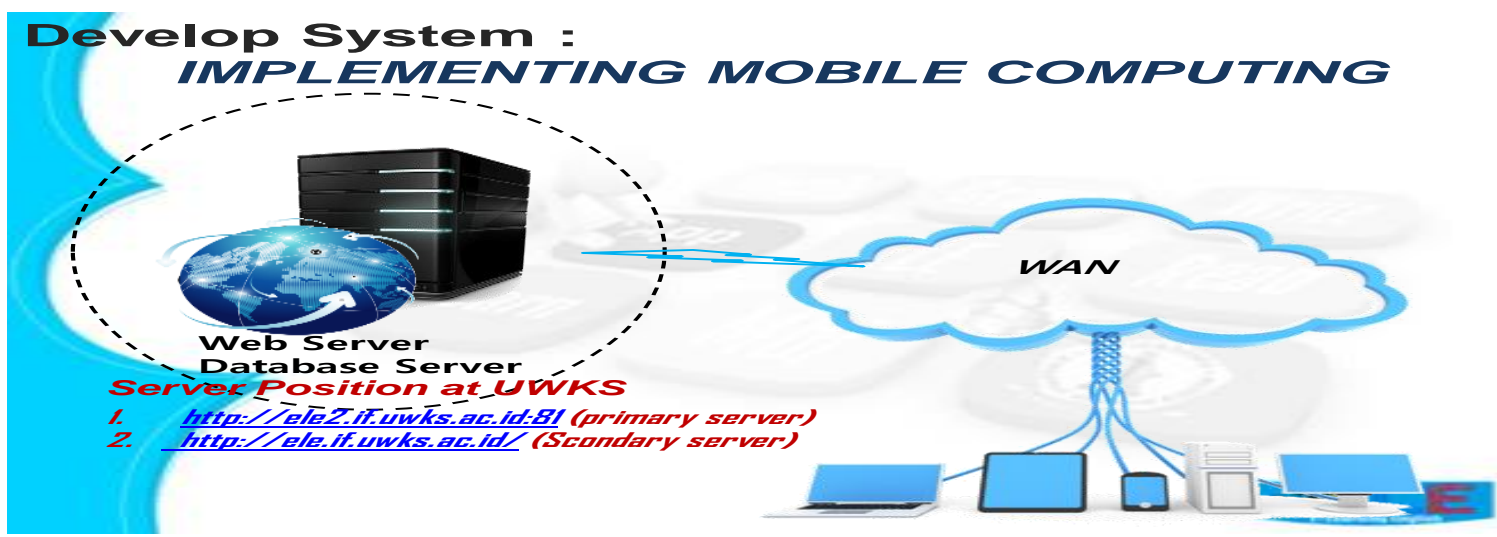

Web and database server physically (hardware) at UWKS, and made a main and backup server 


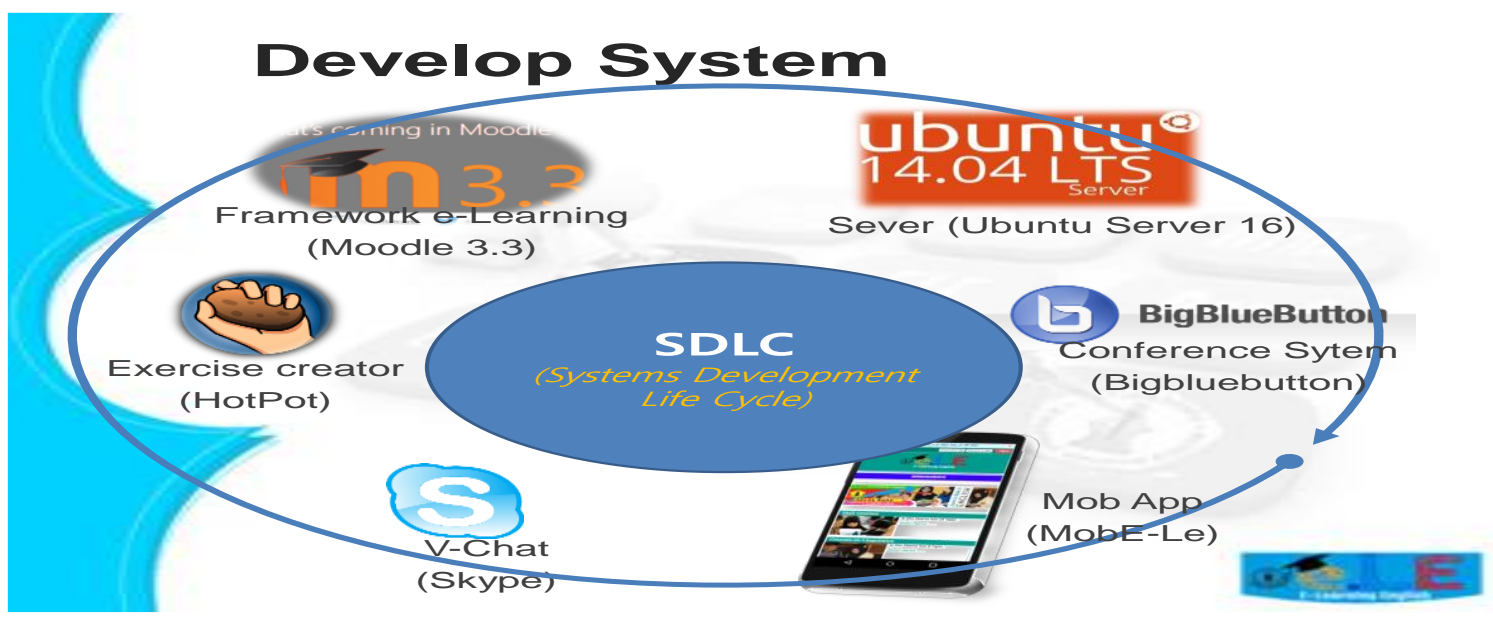

Tools used in making system

Server $\rightarrow$ ubuntu 16

Elearning $\rightarrow$ open source moodle 3.3

Video chat $\rightarrow$ skype.
Zconference $\rightarrow$ bigbluebutton

Making Question $\rightarrow$ hot potatoes

Mobile app $\rightarrow$ android base

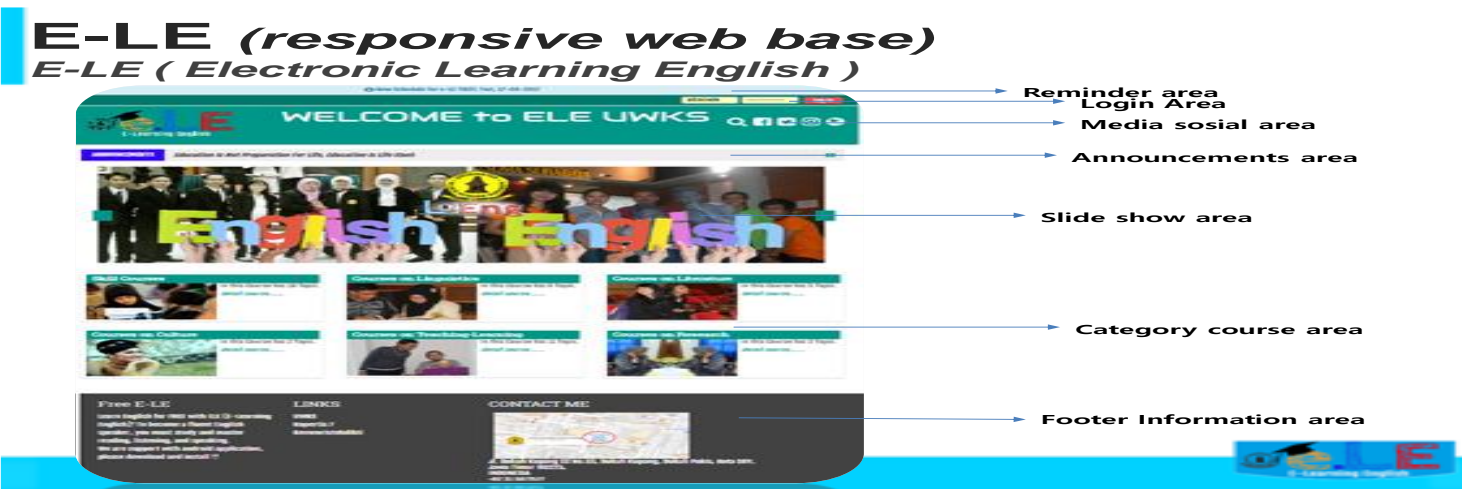

Parts of the Web system

E-LE (web base) THE Types of Privileges User: The Division of User: admin $\rightarrow$ Management the whole system, Lecturers and Students

1. Admin $\rightarrow$ Management System E-LE

2. Lecturer $\rightarrow$ Managemnet Courses, Managemnet Class, Auntentification Students

3. Student $\rightarrow$ Joint Couses, Class, Add Comments, Add Answer

E-LE (web base)

Course Categories
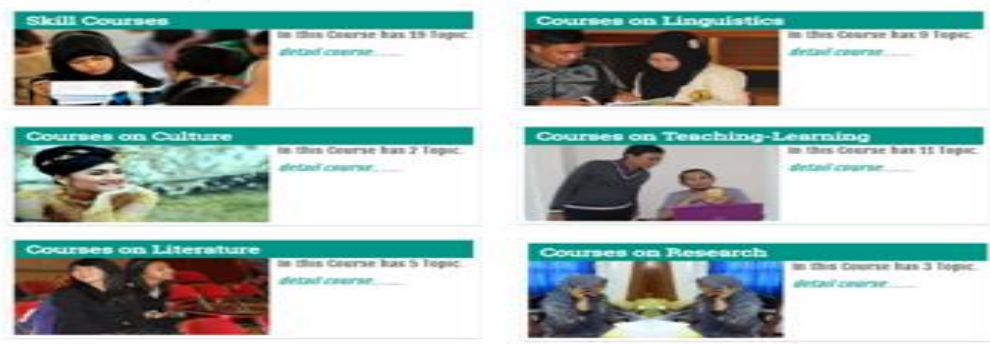
E-LE (web base)

Topic Course ran exampies

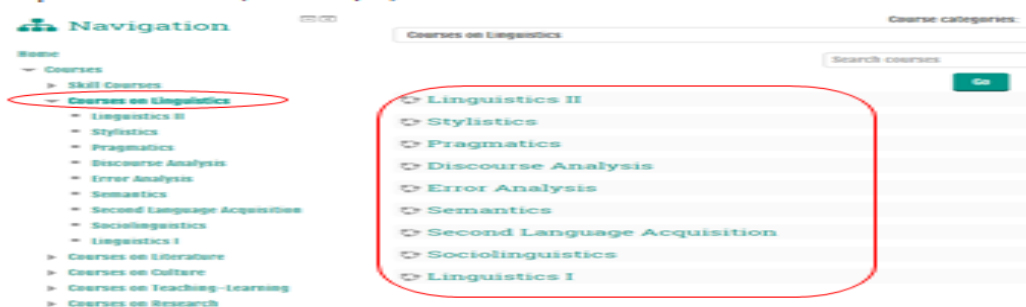

The category of Course for add

The example of the Topic in a Category Course Linguistics

\section{E-LE (welb base)}

Interactive Content
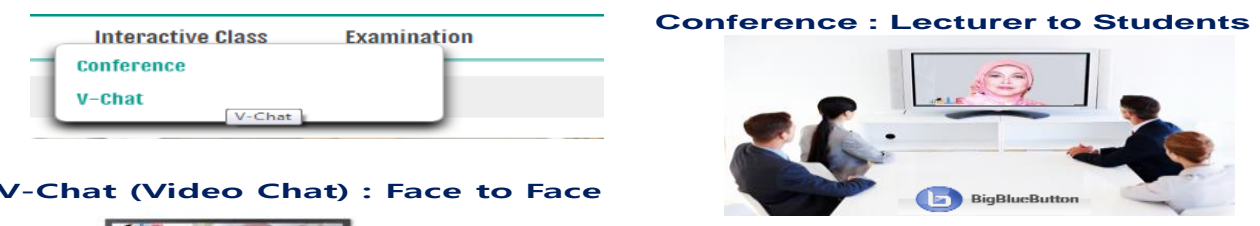

V-Chat (Video Chat) : Face to Face
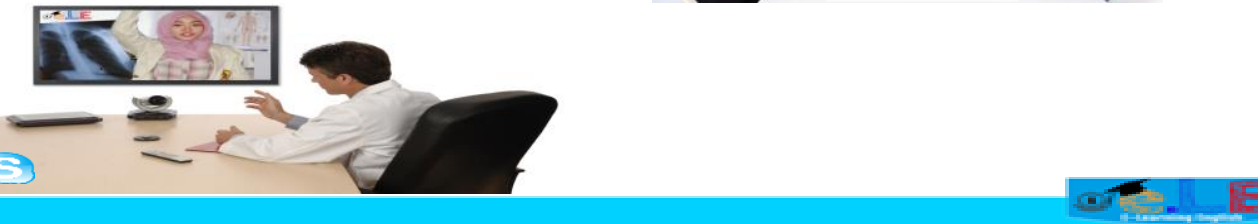

The Interactive Class covering Conference and video Chat

\section{E-LE (web base)}

Interactive Content

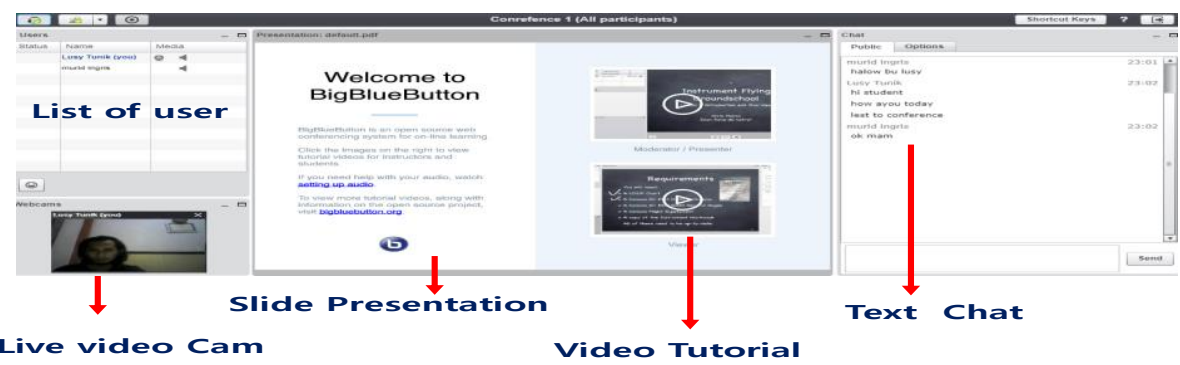

Live video Cam

Video Tutorial

The conferences are: live video, slides presentation, video tutorials, text chatting, list user 


\section{E-LE (web base)}

Exercise Management

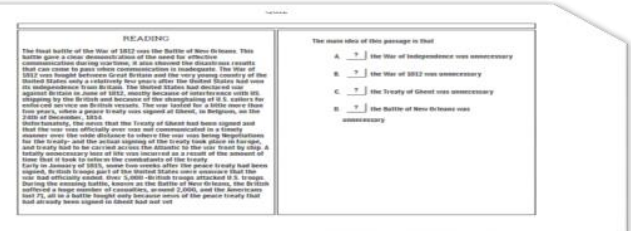

To make the exercises inherence offline on computer lecturer then uploaded to the web e - learning

\section{E-LE (web base)}

Students Answer The Question
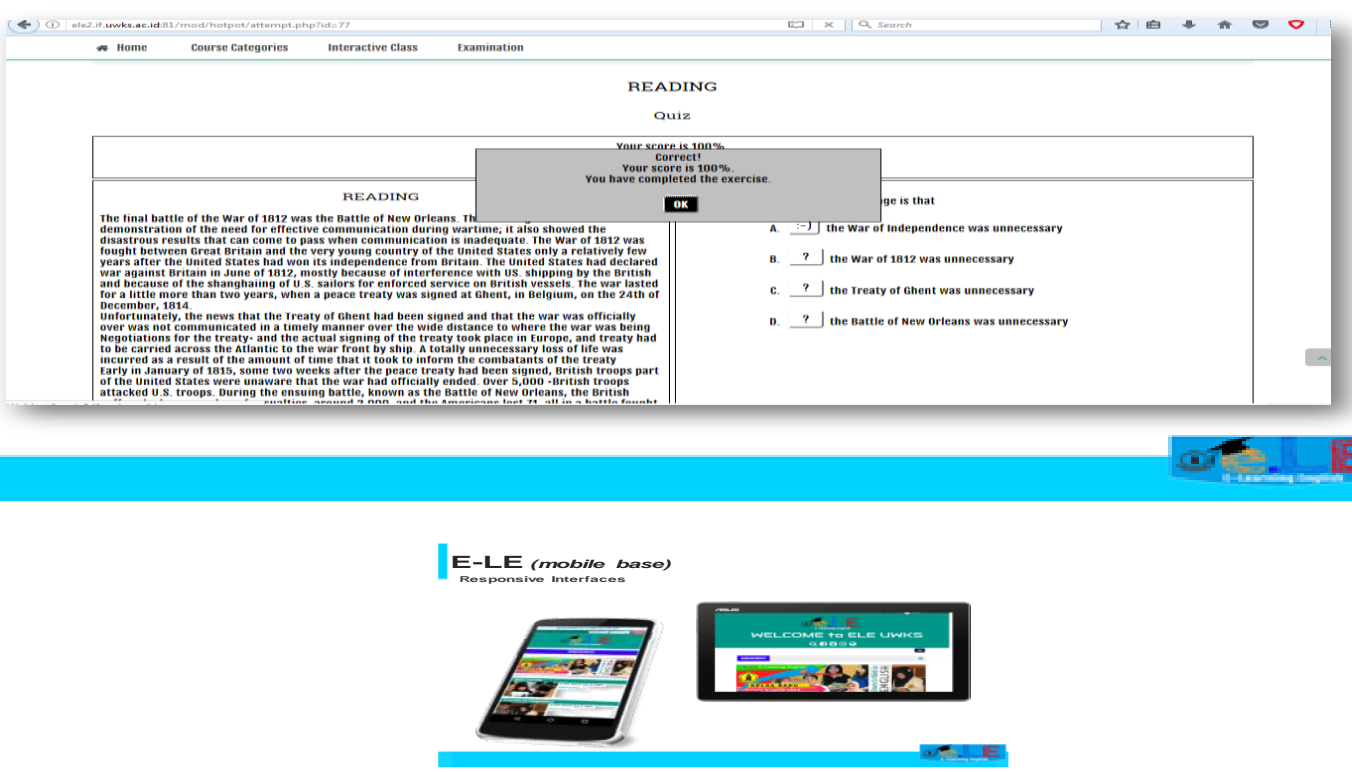

Display responsive (adjust kind of device) 
E-LE (mobile app)

Android base application

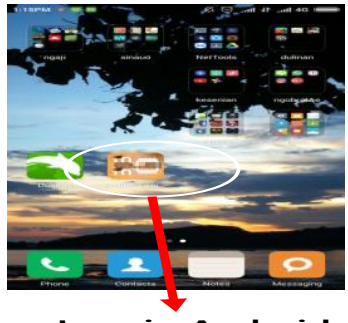

Icon in Android

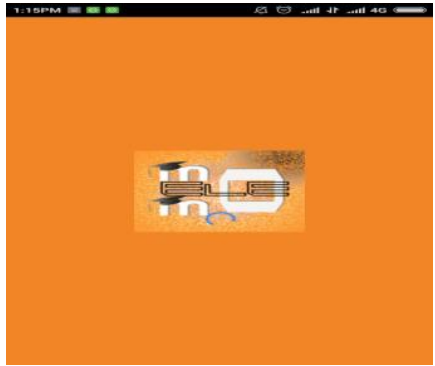

Loading E-LE Mobile

Application based android, the example named MoMo-ELE

E-LE (mobile app)

Android base application

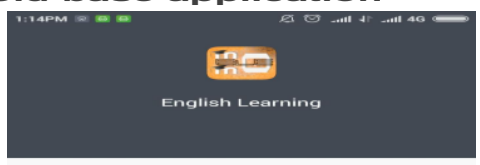

Permission request from Unidentified PC toole

Security
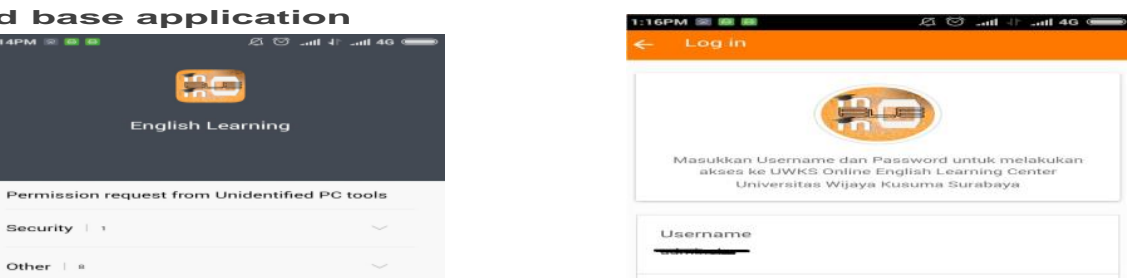

Then when it entered required login

\section{E-LE (mobile app)}

Android base application (conference)
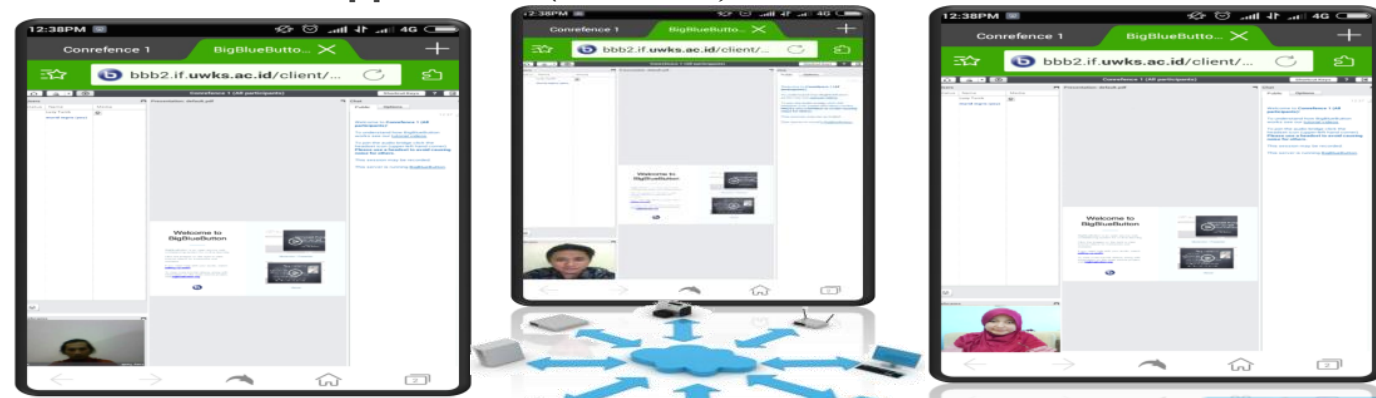

To conference using android

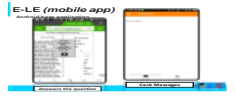

The example using android CONCLUTION AND SUGGESTION 
Based on the results of the research will hopefully 1) contribute to the development of the design computer-based exercises using Weblog, Hot Potatoes Software, and Skype Messengers in creating ideas to facilitate independent learning in reading comprehension for the fourth semester with a set of optimal method, support the development of IPTEKS innovation, have contributed to the renewal and development of ipteks in the desaign learning reading comprehension; 2) contribution to the development, in addressing the problem of development, application of technology towards the commercial, technology transfer, feasibility of Obtaining Patents/Copyrights; 3) Cooperation with Outsiders (new contracts, and royalty), in order of sustainability research is planned to be carried out in a partnership with outside parties especially in other Faculties and together with the University still in Wijaya Kusuma Surabaya to posed in the College's flagship research program and industry; 4) Making materials with the title "Learning Reading Comprehension by using Sotware Hot Potatoes;

\section{REFERENCES}

Clyde, A.L. 2004. Weblogs and Libraries. Great Britain: Chandos Publishing (oxford).

Cohen, L Manion, L \& Marrison K. (2000) and Níkleva, \& López, 2012 "Research Methods in Education ( $5^{\text {th }}$ Edition)" London: Routladge Falmer

Dudeney, Gavin \& Hockly, Nicky. 2007. How to Teach English with Technology. England: Pearson Longman.

Duffy, Peter and Bruns, Axel. 2006. The Use of Blogs, Wikis and RSS in Education: A Conversation of Possibilities. In Proceedings Online Learning and Teaching Conference 2006, pages pp. 31-38, Brisbane.http://eprints.qut.edu.au

Harmer, Jeremy. 2008. How to Teach English: An Introduction to the Practice of English Language Teaching. England: Pearson Longman

Hesmondhalgh (2011) Huette, Scott. 2006. Blogs in Education. (n.d) Retrieved April 4, 2006, from http://awd.cl.uh.edu/blog/

Holmes, Stewart, Arneil, Street. 1998. Hot Potatoes Software. Canada: Victoria University

Hot Potatoes Version 6. Canada: Half-Baked Software, Inc. Retrived December 3, 2010, from http://hotpot.uvic.ca/hotpot6_help.pdf

Gabriella Sandya Puspita Sari. 071214027. "Designing Computer-Based Exercises Using Hot Potatoes Software to Facilitate Independent Learning of Tenses for The First Grade Students of SMK Sanjaya PAKEM" 2012 English Language Education Faculty of Teachers Training \& Education Sanata Dharma University Yogyakarta

Langer and Levy, M. (2007) Computer-Assisted Language Learning: Context and Conceptualization. New York: Oxford University Press.

Martindale, Trey \& Wiley, A.D. 2004. An Introduction to Teaching with Weblogs. http://teachable.org/papers/2004_techtrends_bloglinks.htm 
O’Malley, M.J. \& Pierce, V.L. 2005. Authentic Assessment or English Language Learners:

Practical Approaches for Teachers. Addison- Wesley Publishing.

Paula, Winke. "Review Hot Potatoes". Language Learning and Technology". Volume 5,

Number 2. May 2001

Reeves, Hedberg and Tim Green's 2009. "www.mastersinesl.org/blog/instructionaltechnology- tools-in-the-esl-classroom/". 